\title{
Egg production potentials of certain indigenous chicken breeds from South Africa
}

\author{
J.A.N. Grobbelaar' ${ }^{1}$ B. Sutherland ${ }^{2}$ and N.M. Molalakgotla ${ }^{1}$ \\ ${ }^{1}$ Agricultural Research Council, Livestock Business Division, Irene, Private Bag x2, Irene 0062, South Africa; ${ }^{2}$ Faculty of Science, \\ Department of Animal Sciences, Tshwane University of Technology, Private Bag x680, Pretoria 0001, South Africa
}

\begin{abstract}
Summary
The aim of this study was to determine the egg production potentials of four different indigenous chicken breeds in South Africa: Potchefstroom Koekoek, Venda, Ovambo and Naked Neck. The White Leghorn breed was used as the control. The egg production potentials were evaluated over two consecutive production cycles of 52 weeks (used as replicates). Data were collected at the experimental farm of the Agriculture Research Council at Irene. Treatment means were separated using Fisher's protected $t$-test least significant difference at the 5 percent level of significance and the percentage mortality rate by means of a row by column chi-square test. No significant differences were observed between breeds on the mean age to the production of the first egg. The White Leghorn was superior $(p \leq 0.05)$ to all four of the indigenous breeds for the mean number of eggs and percentage hen-housed egg production produced per production cycle. The Potchefstroom Koekoek was also superior $(p \leq 0.05)$ to the other three indigenous breeds for these parameters. There was no difference between the Ovambo and Naked Neck breeds. The percentage mortality rate for the White Leghorn (39.5 percent) was significantly $(p \leq 0.05)$ different from that of the Venda, Ovambo and Potchefstroom Koekoek (22.2 percent). No differences were observed among the Potchefstroom Koekoek, Venda, Ovambo and Naked Neck (32.3 percent) or between the White Leghorn and Naked Neck with regard to the mean percentage mortality.
\end{abstract}

Keywords: chicken, egg production, indigenous

\section{Résumé}

Le but de l'étude était de déterminer le potentiel de production en œufs de quatre espèces de poules d'Afrique du Sud (Potchefstroom Koekoek, Venda, Ovambo et Naked Neck) ainsi que la Leghorn Blanche. Le potentiel de production en œufs fut évalué sur deux cycles de production consécutifs de 52 semaines (utilisé comme résultats reproductibles). Les données furent recueillies à la ferme expérimentale du Conseil de Recherche Agricole, à Irene. Les moyens de traitement furent séparés en utilisant le test t protégé de Fisher différence la moins significative au niveau d'importance de 5 percent et le pourcentage du taux de mortalité au moyen d'un test d'une ligne par colonne $\chi^{2}$. Aucune différence significative ne fut décelée entre les espèces de l'age moyen jusqu'à la production du premier œuf. Des différences significatives $(\mathrm{p} \leq 0.05)$ se présentèrent pour le pourcentage moyen des poules hébergées et le nombre d'œufs produit par cycle de production entre les Leghorn Blanches et les quatre espèces indigènes. Avec ces paramètres le Potchefstroom Koekoek, diffère de façon significative des autres trois espèces. Aucune différence ne soit obtenue entre le $s$ Ovambo et les Naked Neck. Une différence significative $(\mathrm{p} \geq 0.05)$ c'est produit pour le pourcentage moyen du taux de mortalité entre Les Leghorns Blanches et les Potchefstroom Koekoek, les Venda et les Ovambo. Aucune différence ne fut obtenue entre les Potchefstroom Koekoek, les Venda, les Ovambo et les Naked Neck ainsi que entre les Leghorn Blanches et les Ovambo par rapport au pourcentage moyen de mortalité.

Mots-clés: indigène, poules, production d'oeufs

\section{Resumen}

El objetivo de este estudio fue determinar el potencial de puesta de cuatro diferentes razas locales de gallinas presentes en Sudáfrica. Éstas fueron la Potchefstroom Koekoek, la Venda, la Ovambo y la Naked Neck (cuello desnudo). Se utilizó a la Leghorn Blanca como control. Los potenciales de puesta fueron evaluados a lo largo de dos ciclos consecutivos de producción de 52 semanas (utilizados como duplicados). Los datos fueron tomados en la granja experimental del Consejo de Investigación Agrícola en Irene. Los medios del tratamiento fueron separados utilizando la prueba T protegida de Fisher, diferencia menos significativa al nivel de importancia del 5 percent, y el porcentaje de tasa de mortalidad por medio de una fila a través de la prueba $\chi^{2}$. No se hallaron diferencias significativas entre razas con respecto a la edad de puesta del primer huevo. La Leghorn Blanca fue superior $(\mathrm{p} \leq 0.05)$ en cuanto al número medio de huevos producidos, y para el porcentaje de huevos puestos por ciclo de producción con respecto a las cuatro razas locales. La Potchefstroom Koekoek fue también superior $(\mathrm{p} \leq 0.05)$ con respecto al número de huevos producidos en comparación a las otras tres razas locales para los parámetros mencionados anteriormente. No se evidenciaron diferencias entre la Ovambo y la Naked Neck. El porcentaje de mortalidad para la Leghorn Blanca (39,5 percent) fue significativamente diferente $(\mathrm{p} \leq 0.05)$ a las de la Venda, Ovambo y Potchefstroom Koekoek $(22,2$ percent). No 
se observaron diferencias entre la Potchefstroom Koekoek, la Venda, la Ovambo y la Naked Neck (32,2 percent), o entre la Leghorn Blanca y la Naked Neck, con respecto al porcentaje de mortalidad medio.

Palabras clave: local, gallina, producción de huevos

Submitted 30 June 2008; accepted 10 September 2009

\section{Introduction}

The poultry production systems for egg production in South Africa can be divided into three distinct systems: commercial egg production, semi-intensive egg production and household egg production (South African Poultry Association, 2006). Most of the chicken eggs for human consumption are produced by 319 commercial enterprises in South Africa, which have an estimated 10000 employees (South African Poultry Association, 2006). For the commercial farmer to be financially viable, the following egg production parameters are important:

- the number of eggs produced by a hen in a production cycle must exceed 280 eggs,

- a daily hen-housed egg production of 75 to 95 percent,

- a low mortality rate, and

- an efficient feed conversion ratio.

In contrast to the commercial egg producer, the farmers who want to produce eggs commercially under semiintensive conditions prefer to keep a chicken breed that can produce sufficient eggs, survive under semi-intensive conditions and provide profits. Normally these farmers do not expect the chickens to lay the number of eggs and reach the high percentage of hen-housed egg production achieved by the commercial breeds. However, they need to know the number of eggs produced per hen in a production cycle as well as the daily percentage of hen-housed egg production. This information will enable the farmer to make an informed choice among the different breeds that are available for semi-intensive production.

To produce eggs commercially under a semi-intensive system, the farmer must provide the chickens with sufficient housing, a suitable type of feed and sound general management practices regarding feeding, hygiene and temperature control. Pluimvee Bulletin/Poultry Bulletin (South African Poultry Association, 2006) stated that the number of small-scale egg producing farmers known to them in South Africa is 1745 , and this number was still increasing. The number of eggs produced by these small-scale egg producers is not known.

According to our observations, most of the rural farmers and village households in South Africa keep a few chickens under extensive or semi-intensive conditions with minimum or no input. The birds must scavenge for most of their nutritional needs. No or very little shelter or enclosures are provided. Sonaiya (2003) defined village chickens as involving any genetic stock, improved or unimproved, that was raised extensively or semi-intensively in relatively small numbers (usually less than 100 at a time). Naido (2003) stated that these chickens were left to free range or scavenge for food, with little or no feed supplementation. According to Nhleko et al. (2003), village chickens are among the most adaptable domestic animals that can survive cold and heat, wet and drought, sheltered in cages, unsheltered outside or roosting in trees. Some subsistence farmers keep these chickens for household production (meat and eggs) only. Other subsistence farmers keep them for household production (meat and eggs) and to supplement their income. These farmers want to keep a chicken that can produce sufficient meat and eggs, become broody and hatch their own chickens to make the owner independent in egg and white meat production. Although they raise these chickens, the farmers need a breed with genetic traits for the ability to produce an optimum number of eggs and meat. These chickens must also be able to produce eggs, survive and hatch chickens under extensive conditions.

There are several indigenous chicken breeds in South Africa such as Potchefstroom Koekoek, Venda, Naked Neck, Ovambo, Natal Game, Zulu and Nguni to name a few of the most popular ones. Up to now there was not much detailed information available on the egg production potentials of any of the South African indigenous chicken breeds under either extensive or intensive conditions. Several researchers (Adetayo and Babafunso, 2001; Ramlah, 1996; Yami, 1995) estimated the egg production potential of some of the indigenous chickens of other African countries. These results are published and available to the farmers who want to keep certain types of chickens. Adetayo and Babafunso (2001) reported that the Nigerian indigenous chickens kept in cages and fed commercial feed produced 80 to 90 eggs per hen in a period of 280 days with a mean egg weight of $36.8 \mathrm{~g}$. In Ethiopia these chickens produced between 40 and 99 eggs under extensive conditions per year. The average egg weight was $40 \mathrm{~g}$ per egg in more intensive systems (Yami, 1995). In Malaysia the rate of hen-housed production varied between 17.1 percent using a semi-intensive system and 48.9 percent using an intensive system with egg weights of 42.5 and $46.0 \mathrm{~g}$, respectively (Ramlah, 1996). In Botswana the annual egg production per hen under village conditions ranges from 20 to 100 eggs with an average egg weight of $30-50 \mathrm{~g}$ (Gueye, 1998). If the egg production rates of South African indigenous chickens are available, it will enable the farmer to make an informed choice of which breed to keep from the different indigenous breeds available for semi-intensive egg production. 


\section{Description of the indigenous breeds used in this trial}

To distinguish the indigenous chicken breeds that were used in this study from other indigenous chicken breeds in South Africa, a general description of these birds is provided.

\section{Potchefstroom Koekoek}

According to Fourie and Grobbelaar (2003), the Potchefstroom Koekoek (Figure 1) was bred at the Potchefstroom Agricultural College during the 1950s by a researcher named Marais. This breed is a composite of the White Leghorn, Black Australorp and Bared Plymouth Rock. This breed can therefore be considered as a locally developed breed. The name Koekoek refers to the barred colour pattern of the birds. Most of the laying hens that were available for egg production during the developmental period of the Potchefstroom Koekoek laid white shelled eggs. The consumer, however, preferred brown shelled eggs. Therefore, the Potchefstroom Koekoek was developed for the following specific production traits: the hens should lay a brown shelled egg with an average weight of $55.7 \mathrm{~g}$ and the carcass should be attractive with a deep yellow coloured skin. The Potchefstroom Koekoek cocks and culled hens are used for meat production. Today the meat of this breed is still very popular among local communities and is preferred to that of the commercial broiler hybrids. The Koekoek's colour pattern is a sex-linked gene that is very useful for colour sexing in cross-breeding for egg producing types of hens used in medium input production systems. This breed is very popular among rural farmers in South Africa and neighbouring countries for egg and meat production as well as their ability to hatch their own offspring (Grobbelaar, 2008).

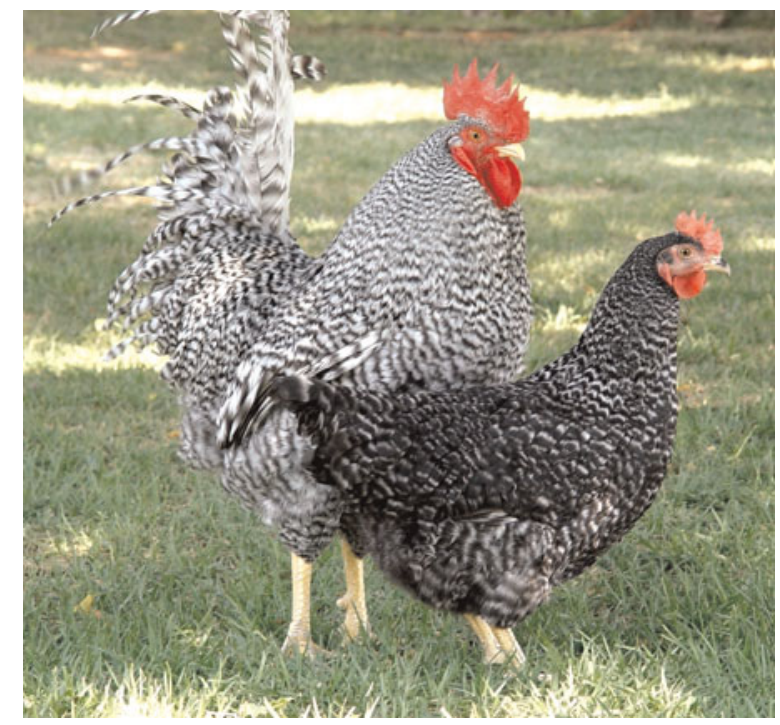

Figure 1. Potchefstroom Koekoek chickens.

\section{Venda}

In 1979 a veterinarian, Dr Naas Coetzee, identified the distinctive Venda chickens (Figure 2) in the Venda area of the Limpopo Province of South Africa and described the breed. Although similar chickens were later identified in the Southern Cape and in the Qua-Qua region of the Free State Province, the name Venda derived from the original description was retained (Fourie and Grobbelaar, 2003). Some of the original chickens were brought to the Poultry Breeding Section of the Agricultural Research Council at Irene for breeding to prevent the breed from becoming extinct.

\section{Ovambo}

A researcher at the Poultry Breeding Section at Irene visited the Ovamboland District of Namibia in 1975 and saw the Ovambo breed (Figure 3). He collected some of these chickens and brought them to the Poultry Breeding Section of the Agricultural Research Council at Irene to establish a stock colony and prevent the breed from becoming extinct (Fourie and Grobbelaar, 2003).

\section{Naked Neck}

The origin of the Naked Neck breed (Figure 4) is disputed, but the breed was probably introduced by early traders from Malaysia on their journey around the continent (van Marle-Koster and Nel, 2000). It is therefore possible that the Dutch East Indian Company introduced Naked Neck chickens in the seventeenth century to the Cape of Good Hope (Fourie and Grobbelaar, 2003). Therefore, this breed is recognized as an indigenous breed. The Naked Neck is a very adaptable breed and can be found all over South Africa, even in diverse climates.

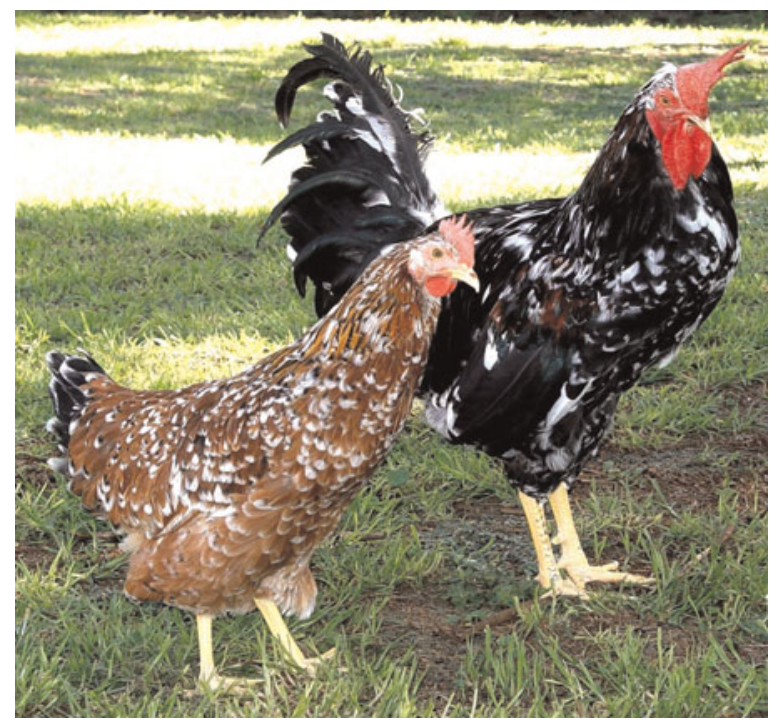

Figure 2. Venda chickens. 


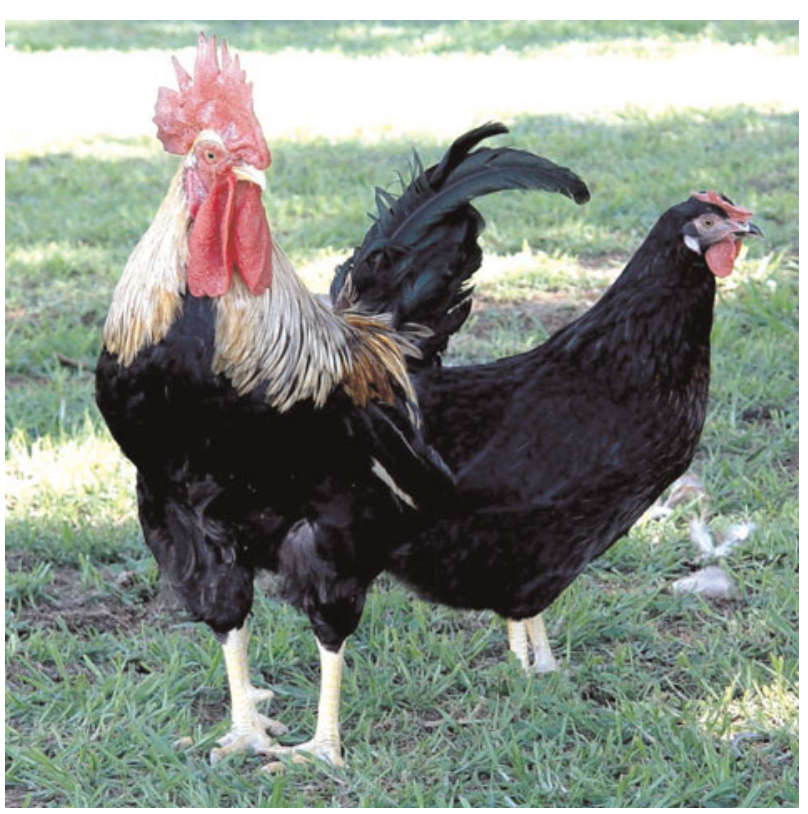

Figure 3. Ovambo chickens.

\section{Adaptability of the Venda, Ovambo and Naked Neck}

The Venda, Ovambo and Naked Neck breeds can easily fly into trees to roost for the night or to escape ground predators. These chickens have a variety of colour patterns, which assist in camouflaging to protect them from ground predators. These breeds are well adapted to diverse temperatures and to scavenging for food. They will eat anything from grass seeds, household scraps and insects to small rodents. Some farmers use these breeds for natural tick and fly control by placing a movable chicken house at their kraals or by having a chicken house close to their dairy. These breeds are well suited for use in rural areas for egg and meat production. These breeds get broody and will hatch their own chickens (Fourie and Grobbelaar, 2003).

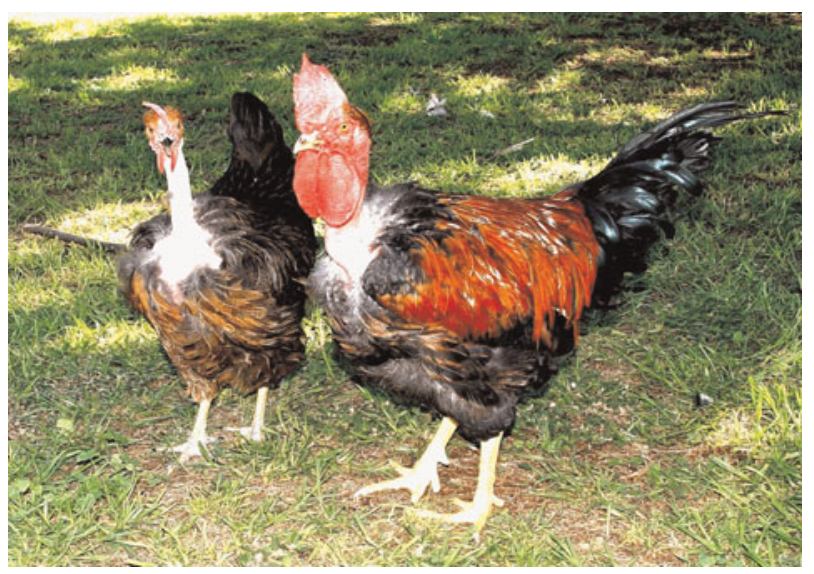

Figure 4. Naked Neck chickens.

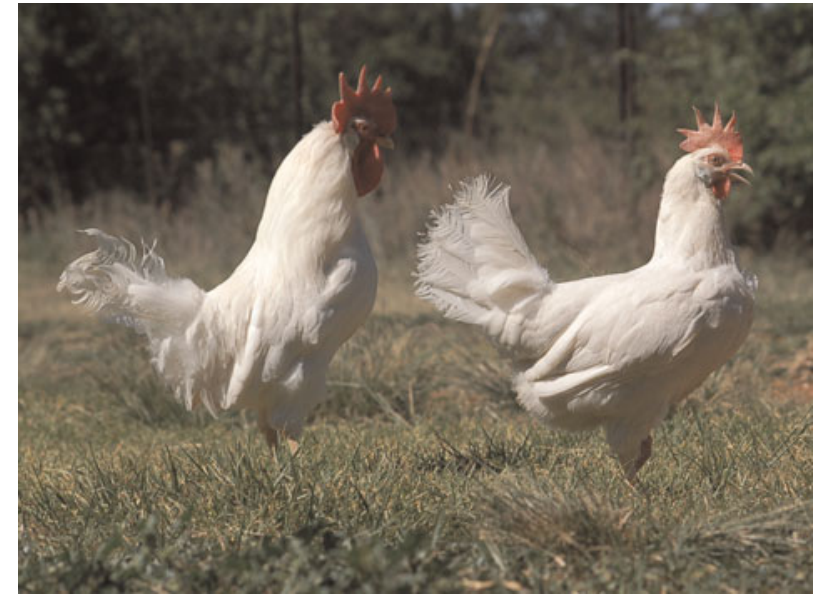

Figure 5. White Leghorn chickens.

\section{White Leghorn}

According to Viljoen (1979), the White Leghorn (Figure 5) is one of the oldest chicken breeds known to humans. This breed originated in Italy and was already well known during the Roman Empire. This breed was exported to the United States of America, the United Kingdom and Australia early in the nineteenth century. The Leghorn was solely bred as an egg producer and is widely used in cross-breeding to develop new layer hybrids. Viljoen (1979) also stated that during the 1940s the South African Leghorns came mostly from England, America and Denmark. Generally, this breed is not broody.

\section{Materials and methods}

Our investigation was conducted on the experimental farm of the Agriculture Research Council at Irene. Irene is a village approximately $20 \mathrm{~km}$ south of Pretoria in the Gauteng Province of South Africa. It is situated at latitude $25.91^{\circ}$ and longitude $28.21^{\circ}$ with an altitude of $1526 \mathrm{~m}$ above sea level and has an annual average rainfall of $717 \mathrm{~mm}$.

To be able to determine the egg production potentials of the four indigenous breeds (Potchefstroom Koekoek, Venda, Ovambo and Naked Neck), a trial was conducted over two consecutive egg production cycles of 52 weeks each, commencing in 2001. The chickens used in this trial were hatched from the parent stock kept at the Poultry Breeding Section of the Live Stock Business Division of the Agriculture Research Council at Irene. No selection for the improvement of egg production was performed on the parent stock colonies during the last 25+ years, and no selection was applied during any of the experimental years.

The experimental birds were kept on a deep litter floor system in naturally ventilated houses $(45 \times 12 \mathrm{~m}$ and $2.5 \mathrm{~m}$ high). For the control of ventilation and heat, the houses 
were equipped with adjustable plastic curtains. Each house contained 60 individual cages that were $4 \times 2 \mathrm{~m}$ and $1.8 \mathrm{~m}$ high. Each cage was equipped with one automatic Bell-drinker, one self-feeder and one nesting box with five nests.

For both years the experimental hens were reared from 1 day old to 16 weeks of age in an environmentally controlled house containing individual cages that were $3.0 \times 4.0 \mathrm{~m}$ and $1.5 \mathrm{~m}$ high. The chickens were raised under infrared brooders (100 chickens per lamp) up to 4 weeks of age using the normal prescribed temperatures for rearing chickens. The chickens were fed a commercial pullet starter (19 percent protein) for the first 2 weeks and a pullet grower (15 percent protein) until the hens started to lay. The lighting regime, as previously used at the poultry breeding section, was 23 hours light for the first week, 20 hours light for the second week and 17 hours up to 16 weeks of age. At the age of 16 weeks the chickens were placed in the laying houses. All hens that reached maturity were kept to replenish the parent stock colony. The cocks were selected for their physical appearance in regard to size, head formation, legs, toes and colour patterns, according to the breed standards (Figures 1, 2, 3, 4 and 5). During the experimental period a standard commercial laying pellet (105) from ALZU Feeds ${ }^{\circledR}$ was used and fed ad lib. The chickens had free access to clean drinking water supplied by the local authority. A constant daylight length of 17 hours was maintained throughout the study. Eggs were collected twice daily: in the morning at 8:30 a.m. and in the afternoon at 2:00 p.m. To ensure that there was no mixing of eggs between the breeds, the identification of the breed was written on each egg. All eggs were recorded in the egg record book of the Poultry Section and captured with the Eggs $2000^{\circledR}$ computer program. The eggs were sorted by removing the dirty and cracked eggs from the egg trays. The remainder of the eggs were then graded into small $(<43 \mathrm{~g})$, medium (44-50 g), large (51-61 g), extra large $(62-66 \mathrm{~g})$ and jumbo $(>66 \mathrm{~g})$ by means of a Moba grading machine.

\section{Number of hens that were kept}

The numbers of hens per breed that were kept during the 2 years of the experiment are described in Table 1.

Table 1. The number of experimental hens kept per breed per year.

\begin{tabular}{lcr}
\hline Breed & \multicolumn{2}{c}{ Number of hens per year } \\
\cline { 2 - 3 } & $\mathbf{2 0 0 1}$ & $\mathbf{2 0 0 2}$ \\
\hline Potchefstroom Koekoek & 76 & 100 \\
Ovambo & 96 & 100 \\
Venda & 67 & 100 \\
Nacked Neck & 48 & 62 \\
White Leghorn & 80 & 135 \\
\hline
\end{tabular}

\section{Data collected for each year}

The data collected over a 52-week period were the age of the hens at the time of laying the first egg (sexual maturity), mean number of eggs laid per bird, percentage daily hen-housed egg production, number of eggs per grade and mortality.

\section{Determination of sexual maturity}

To determine the period to sexual maturity, the number of days to the production of the first egg (of the group) was calculated from the hatching date of the hen to the production of the first egg.

\section{Determination of total number of eggs produced per production cycle}

The total number of eggs produced per hen per production cycle of the two 52-week production cycles was calculated as follows:

Total number of eggs produced (per breed) for a month Total number of hens (per breed) alive during the month

The total number of eggs per hen per month was then added together to determine the total number of eggs per hen per production cycle over the two 52 -week production cycles. The average for the two production cycles was then calculated.

\section{Determination of daily percentage of hen-housed egg production}

The daily percentage of hen-housed egg production over the two 52-week production cycles was calculated according to the method described by North and Bell (1990, p. 350):

$$
\frac{\begin{array}{c}
\text { Average daily number of } \\
\text { eggs produced } \times 100
\end{array}}{\text { Number of hens housed }}=\begin{aligned}
& \text { daily percentage of } \\
& \text { hen-housed egg } \\
& \text { production for the period. }
\end{aligned}
$$

Further, the area under the curve for the daily percentage hen-housed egg production over 13 months was calculated to determine the significant difference between the daily percentage of hen-housed egg production.

\section{Statistical analyses}

Data on the age at first egg, mean number of eggs laid per bird and daily egg production were collected each year for the group rather than for individual hens. Thus, the 2 years of data were used as blocks in the randomized complete 
block design and the year by breed interaction effect was used as the estimate of the error variance.

The model for the randomized complete block design testing for differences between breeds was the following:

$$
Y_{i j}=\mu+\alpha_{i}+\varepsilon_{i j},
$$

where $Y_{i j}$ is the measurement for the $i$ th breed and $j$ th year, $\mu$ is the overall mean effect, $\alpha_{i}$ is the $i$ th breed effect and $\varepsilon_{i j}$ is the random error variation.

Treatment least square means were separated using Fisher's protected $t$-test least significant difference at the 5 percent level of significance $(p \leq 0.05$; Snedecor and Cochran, 1980) for the egg production parameters. These parameters are the mean age of the hens (days) to the production of the first egg, the mean distribution of egg quality and grades, the mean percentage of hen-housed egg production and the mean number of eggs produced per hen per year.

The significance of the mortality rate was tested using a row by column chi-square test.

\section{Results and discussion}

There were no significant differences $(p=0.33)$ among breeds in the mean age to the production of the first egg. Although the data indicated no significant differences among the breeds, the Naked Neck (129.0 days) and White Leghorn (120.5 days) tend to produce their first egg at a younger age than the Potchefstroom Koekoek (138.5 days), Venda (139.0 days) and Ovambo (134.5 days). These findings are in contrast to the sexual maturity (production of first egg) found by Ramsy, Harris and Kotze (no date), who stated that the sexual maturity for the Potchefstroom Koekoek was 130 days, the Venda 143 days, the Ovambo 143 days and the Naked Neck 155 days. The difference between the results obtained during this investigation and the results obtained by Ramsy et al. (no date) could be attributed to various factors such as the rearing process. Ramsy et al. gave no indication of the method of rearing. Demeke (2004) reported that in a trial conducted in Ethiopia the comparative egg production performance of local Ethiopian hens and White Leghorn hens under rural household conditions, a combination of rural household conditions plus $50 \mathrm{~g}$ of commercial supplementary feed and intensive conditions, the mean days to sexual maturity for the White Leghorn were 165, 158 and 149 days, respectively. These results obtained by Demeke's (2004) results were not only in contrast to the results obtained for the White Leghorn of 120.5 days during this trial, but they also emphasized the effect on the mean days to sexual maturity by the methods used during rearing. The early sexual maturity obtained for the Naked Neck and White Leghorn, compared to the other indigenous breeds of South Africa, during this trial can most likely only be attributed to genetic differences because all the chickens were reared under identical environmental conditions such as housing, lighting and nutrition.

No significant differences among the breeds for cracked, dirty, small, medium, large and extra-large eggs were found (Table 2). The White Leghorn and Ovambo produced higher percentages of jumbo eggs than the rest of the breeds, especially at the later stage of the production cycle. It is impossible to compare the above-mentioned egg quality and sizes to other findings in the literature because the literature only gives the mean egg weights. Adetayo and Babafunso (2001) reported that the mean egg mass of the Nigerian indigenous chickens was $36.8 \mathrm{~g}$. Gueye (1998) indicated that the mean egg mass of the indigenous chickens in Ethiopia was $40 \mathrm{~g}$ using an intensive system during trials conducted at the Jimma College of Agriculture. Nhleko et al. (2003) reported that the mean mass of eggs collected from indigenous chickens from subsistence households in the rural district of Paulpietersburg, northeastern Kwazulu-Natal, South Africa, was $48.9 \mathrm{~g}$. Although the above-mentioned authors reported the mean egg weights, no indication of the percentages of small, medium, large, extra large and jumbo were given. During this investigation a complete study was conducted of the different economic egg grades that were available as sellable eggs. Although these indigenous chickens did not produce the high numbers of eggs per

Table 2. Least square mean percentage distributions of egg quality and grades.

\begin{tabular}{|c|c|c|c|c|c|c|c|}
\hline Breed & Cracks & Dirty & Small & Medium & Large & Extra Large & Jumbo \\
\hline Potchefstroom Koekoek & 2.80 & 4.25 & 4.27 & 22.00 & 61.14 & 2.05 & 3.49 \\
\hline Venda & 2.80 & 5.84 & 3.28 & 26.87 & 59.54 & 0.03 & 1.64 \\
\hline Ovambo & 3.65 & 11.64 & 3.79 & 17.74 & 56.42 & 0.07 & 6.69 \\
\hline Naked Neck & 2.49 & 3.70 & 8.02 & 23.36 & 57.96 & 0.95 & 3.52 \\
\hline White leghorn & 2.32 & 8.95 & 3.35 & 10.93 & 62.85 & 3.95 & 7.65 \\
\hline SEM & 0.355 & 3.7 & 1.29 & 3.42 & 3.24 & 1.656 & 1.092 \\
\hline$F$ probability & 0.249 & 0.574 & 0.212 & 0.143 & 0.676 & 0.503 & 0.069 \\
\hline $\operatorname{LSD}(5 \%)$ & Not applicable & & & & & & \\
\hline CV $(\%)$ & 17.8 & 76.1 & 40.1 & 23.9 & 7.7 & 165.6 & 33.5 \\
\hline
\end{tabular}

Note: SEM, standard error of the mean.

LSD, least significant difference at the $5 \%$ level; CV, coefficient of variation. 
Table 3. Least square mean area under the curve percentage of daily hen-housed egg production for the two production cycles.

\begin{tabular}{lc}
\hline Breed & Mean area under the curve \\
\hline Potchefstroom Koekoek & $618.6^{\mathrm{b}}$ \\
Venda & $489.2^{\mathrm{c}}$ \\
Ovambo & $400.7^{\mathrm{d}}$ \\
Naked Neck & $443.1^{\mathrm{cd}}$ \\
White leghorn & $872.6^{\mathrm{a}}$ \\
SEM & 15.69 \\
$F$ probability & 0.001 \\
Least significant of means (5\%) & 61.59 \\
CV (\%) & 3.9 \\
\hline
\end{tabular}

Note: Breeds with different superscripts differ significantly at $p \leq 0.05$. $\mathrm{SEM}$, standard error of the mean; $\mathrm{CV}$, coefficient of variation.

year (in excess of 280) of the modern commercial hybrids, the number of sellable eggs produced by these hens was high (Potchefstroom Koekoek, 92.9 percent out of 195.9 eggs; Venda, 91.34 percent out of 153.7 eggs; Ovambo, 84.71 percent out of 125.5 eggs; Naked Neck, 97.99 percent out of 138 eggs).

There was a significant difference $(p \leq 0.05)$ in the calculated area under the curve for the daily percentage of hen-housed egg production per production cycle (Table 3$)$ between the White Leghorn ( 83.2 percent) and the Potchefstroom Koekoek (67.8 percent), Venda (54.0 percent), Ovambo (42.0 percent) and Naked Neck (57.5 percent). Between the indigenous breeds there was a significant difference $(p \leq 0.05)$ in the daily hen-housed egg production percentage between the Potchefstroom Koekoek that had the highest daily hen-housed egg production percentage and the Venda, Ovambo and Naked Neck. There was also a significant difference $(p \leq 0.05)$ for the daily hen-housed egg production percentage between the Venda and Ovambo. There was no significant difference for the daily hen-housed egg production percentage between the Naked Neck and Ovambo or the Naked Neck and Venda. According to Ramlah (1996), the daily hen-housed egg production was 29.3-48.9 percent in

Table 4. Least square mean of number of eggs produced per hen over two 52-week production cycles.

\begin{tabular}{lc}
\hline Breed & Number of eggs per hen \\
\hline Potchefstroom Koekoek & $195.9^{\mathrm{b}}$ \\
Venda & $153.7^{\mathrm{c}}$ \\
Ovambo & $125.5^{\mathrm{d}}$ \\
Naked Neck & $138.9^{\mathrm{cd}}$ \\
White Leghorn & $279.5^{\mathrm{a}}$ \\
SEM & 5.3 \\
F probability & 0.001 \\
LSD & 20.75 \\
CV & 4.2
\end{tabular}

Note: Breeds with different superscripts differ significantly at $p \leq 0.05$. $\mathrm{SEM}$, standard error of the mean; LSD, least significant difference; CV, coefficient of variation.
Malaysia under intensive conditions. The South African indigenous chickens, with the exception of the Ovambo, performed much better than the indigenous breeds of Malaysia under comparable conditions.

A significant difference $(p \leq 0.05)$ for the number of eggs produced per production cycle (Table 4) was observed between the White Leghorn, which produced 275.9 eggs per year, and the Potchefstroom Koekoek (195.9), Venda (153.7), Naked Neck (138.9) and Ovambo (125.5). For the indigenous breeds, a significant difference $(p \leq 0.05)$ for the number of eggs per hen per year was obtained between the Potchefstroom Koekoek and the other three indigenous breeds. There was also a significant difference $(p \leq 0.05)$ between the Venda and Ovambo. There was no significant difference between the Naked Neck and the Ovambo or the Naked Neck and Venda. The number of eggs per hen per production cycle of the four indigenous chicken breeds of South Africa was determined by Van Marle-Koster and Casey (2001), who kept the chickens in battery cages in an environmentally controlled house. They obtained 204 eggs per hen per production cycle (51 weeks) for the Potchefstroom Koekoek and 139 eggs per production cycle for the Naked Neck. These findings were similar to those obtained in this trial for the 195.9 eggs per production cycle for Potchefstroom Koekoek and the 138.9 eggs for the Naked Neck. In contrast, they obtained 122 eggs per production cycle for the Venda and 91 eggs for the Ovambo. The number of eggs per production cycle was much lower than the number of eggs per production cycle of 153.7 for the Venda and 125.5 for the Ovambo obtained during this trial. These results support the number of eggs obtained during this trial for the Potchefstroom Koekoek and the Naked Neck, but they are in contrast to the number of eggs obtained for the Venda and Ovambo. The contrast in the number of eggs produced in this trial and that obtained by Van Marle-Koster and Casey (2001) for the Venda and Ovambo might be because the hens were kept under different conditions.

The South African indigenous chickens generally performed much better in all egg production parameters evaluated during this investigation under intensive conditions than those reported in other African countries. This might be attributed to the genetic potential as well as the feed composition and housing provided for the indigenous chicken breeds of South Africa.

The percentage of mortality of White Leghorn (39.5 percent) was significantly $(p \leq 0.05)$ different from that of the Potchefstroom Koekoek (22.2 percent), Venda (19.2 percent) and Ovambo (19.9 percent), but did not differ from the Naked Neck (32.9 percent). The high mortality rate of the White Leghorn may be ascribed to the poor adaptability of the chickens when placed in the laying house. Approximately 15 percent of the hens died in the first 3 months after they were placed in the laying house. 


\section{References}

Adetayo, A.S. \& Babafunso, S.E. 2001. Comparison of the performance of Nigerian indigenous chickens from three agro-ecological zones. Livestock Res. Dev., 13: 2 (available at http://www.cipav.org.co/lrrd/ lrrd13/2aded132.htm)

Demeke, S. 2004. Egg production performance of local and White Leghorn hens under intensive and rural household conditions in Ethiopia. CIPAV (available at http://www.cipav.org.co/lrrd//rrd16/2/deme1602. $\mathrm{htm})$.

Fourie, C. \& Grobbelaar, J.A.N. 2003. Indigenous poultry breeds, pp. 20-21. Krugersdorp, Germany, Wing Nut Publications.

Grobbelaar, J.A.N. 2008. Egg production potentials of four indigenous chicken breeds in South Africa. Pretoria, Tshwane University of Technology. (M.Tech. thesis)

Gueye, E.F. 1998. Village egg and chicken meat production in Africa. World Poult. Sci. J., 54: 73-85.

Naidoo, M. 2003. Indigenous poultry production systems in Northern Kwazulu-Natal, South Africa, pp. 66-73. Paper presented at the 1st National Workshop on Indigenous Poultry Development, Nature and Development Group of Africa (NGO Registration No. 026-851-NPO).

Nhleko, M.J., Slippers, S.C. \& Nsahlai, I.V. 2003. A preliminary report of on-farm performance of rural chickens kept under farmers' management, pp. 79-83. Paper presented at the 1st National Workshop on Indigenous Poultry Development, Nature and Development Group of Africa (NGO Registration No. 026-851-NPO).

Nhleko, M.J., Slippers, S.C., Lubout, P.C. \& Nsahlai, I.V. 2003. Characterisation of the traditional poultry production in the rural agricultural system of Kwazulu-Natal, pp. 74-78. Paper presented a the 1st National Workshop on Indigenous Poultry Development,
Nature and Development Group of Africa (NGO Registration No. 026-851-NPO)

North, M.O. \& Bell, D.D. 1990. Commercial chicken production manual, 4th edition. New York, Van Nostrand Reinhold.

Ramlah, A.H. 1996. Performance of village chickens in Malaysia. World Poult. Sci. J., 52: 75-79.

Ramsy, K., Harris, L. \& Kotze, A. No date. Sa. Landrace breeds: South Africa's indigenous and locally developed farm animals. Pretoria, Farm Animal Conservation Trust.

Snedecor, G.W. \& Cochran, W.G. 1980. Statistical methods, 7th edition, p. 507. Ames, IA, USA, Iowa State University Press.

Sonaiya, E.B. 2003. Village poultry and its role in rural Africa, pp. 1630. Paper presented at the 1st National Workshop on Indigenous Poultry Development, Nature and Development Group of Africa (NGO Registration No. 026-851-NPO).

South African Poultry Association. 2006. Official mouthpiece of the South African Poultry Association. Pluimvee Bull./Poult. Bull., April: 166.

Van Marle-Koster, E. \& Nel, L.H. 2000. Genetic characterization of native southern African chicken populations: evaluation and selection of polymorphic microsatellite markers. S. Afr. J. Anim. Sci., 30(1): $1-6$.

Van Marle-Koster, E. \& Casey, N.H. 2001. Phenotypic characterisation of native chicken lines in South Africa. Anim. Genet. Resour. Info., 29: $71-78$.

Viljoen, W.C.J. 1979. Hoenderrasse - pluimvee. Boerdery in Suid Afrika, Pamphlet A.2. Pretoria, Department of Agriculture and Water Supply.

Yami, A. 1995. Poultry production in Ethiopia. World Poult. Sci. J., 51: 197-201. 